\title{
Paper sludge induced physiological changes in the antioxidative response system of Solanum melongena $\mathrm{L}$.
}

\author{
Manorama Mishra ${ }^{1}$ and Surjendu Kumar Dey ${ }^{2}$ \\ 1 (Research Scholar, P.G Department of Environmental Science, Fakir Mohan University, Balasore-756020, \\ India) \\ 2 (Reader, P.G Department of Environmental Science, Fakir Mohan University, Balasore-756020, India)
}

\begin{abstract}
Safe and economical disposal of paper mill sludge is a key to pollution free environment. A study was conducted to examine the effect of paper sludge amendment on the antioxidant defence system of Solanum melongena $L$. The changes in the activities of antioxidant enzymes like superoxide dismutase, catalase and peroxidase along with level of lipid peroxidation were comparatively studied. Treatments with five replicates consisted of 0, 10, 20, 50 and 80\% paper mill sludge. Leaves of both control and treated seedlings were taken for experiment. The activities of catalase and peroxidase were found to be maximum in $10 \%$ sludge treatment indicating the maximum protection against oxidative damage. Superoxide dismutase activity was also found to be highest in 10\% sludge showing the increasing capacity of the cells to scavenge the superoxide radicals generated. The lower level of lipid peroxidation in 10\% sludge indicated the ideal condition for healthy growth of the plant.
\end{abstract}

Key words: Antioxidant enzymes, lipid peroxidation, oxidative damage, paper mill sludge

\section{Introduction}

The extensive developmental activities like industrialization and urbanization carried out during the past few years have given rise to significant increase in environmental contamination. The natural ecosystem is being polluted from wastes generated from different industries. The industrial paper recycling processes produce a huge amount of organic waste known as sludge, which is unsuitable for the production of new paper (Billitewski et al., 1990) and its huge gathering in the environment has become a challenge through out the world. So, a new strategy for management of paper mill sludge as agricultural amendment is being developed. Paper mill sludge is known to contain a high percentage of lignin, cellulose, hemicellulose, chlorolignin, tannin, resin acids, fatty acids, sodium sulphate, calcium carbonate, organochlorines etc (Hocking, 1991). As the raw materials used for paper manufacturing are originated from plant, the sludge has significant amount of nutrients. Hence, proposed for use in agriculture (Beyer and Mueller, 1995). Apart from the nutrient content, paper sludge also contains some heavy metals like $\mathrm{Cd}, \mathrm{Hg}, \mathrm{Pb}$ and $\mathrm{Al}$ (Edwards, 1997). Thus, when paper sludge is applied in fields, plants will absorb the heavy metals along with the nutrient contents. Heavy metals interfere with the various metabolic processes of the living system and create physiological changes leading to oxidative stress. One of the major consequences of oxidative stress is the increased production of reactive oxygen species (ROS), which impair cell membranes, nucleic acids and pigments of chloroplast (Somashekaraiah et al.,1992; Chaoui et al., 1997; Weckx and Clijsters, 1997; Fang and Kao, 2000; Tewari et al., 2002). Plants have evolved various protective mechanisms like enzymatic antioxidant system to reduce the reactive oxygen species. The representatives of enzymatic antioxidant system include the activities of catalase, peroxidase and superoxide dismutase. The main focus of this study is to determine the response of antioxidative enzymes in brinjal plants grown with paper sludge amended soil. Reports regarding the amendment of paper mill sludge on the antioxidative system of plant are rare. Therefore, in this study attempts have been made to determine the antioxidative response system of Solanum melongena $\mathrm{L}$. with respect to rate of application of paper mill sludge. The parameters selected for study include catalase, peroxidase, superoxide dismutase and lipid peroxidation.

\section{Materials And Methods}

Plant material and growth conditions

Paper mill sludge from secondary clarifier of Emami paper mills Pvt. Ltd, Balgopal pur, Balasore was collected. After collection, it was kept for some days for loss of moisture. Treatments were done in earthen pots containing 10,20, 50 and $80 \%$ paper mill sludge along with soil. A control was maintained by mixing cow dung compost with soil. Healthy and uniform seeds of Solanum melongena L. Cv. Pusa uttam were collected and saplings were raised in the nursery bed. Three week old saplings were transferred from nursery bed and one sapling was planted in each pot. All the treatments and control were maintained in field condition and were watered regularly with tap water. After 30 days, the antioxidative efficiency of the plant was assessed by measuring the activities of antioxidative enzymes along with level of lipid peroxidation in leaf tissues. 


\section{Biochemical analyses}

Following the method of Heath and Packer (1968), malondialdehyde (MDA), an index of lipid peroxidation was extracted with 5\% Trichloroacetic acetic acid and was estimated taking thiobarbituric acid as the reactive material.

For enzyme extraction, the leaf tissues were homogenised under ice-cold conditions with a mortar and pastle using 50mM sodium phosphate buffer, $\mathrm{pH} 7.5$ for catalase and peroxidase and $\mathrm{pH} 7.4$ for superoxide dismutase. The homogenates were centrifused at $10,000 \mathrm{rpm}$ at $-14^{0} \mathrm{C}$ for $10 \mathrm{~min}$ and the resulting supernatants were collected separately for enzyme assay, after suitable dilutions.

Catalase (EC 1.11.1.6) activity was determined following the method of Aebi (1983) and here the decrease in $\mathrm{H}_{2} \mathrm{O}_{2}$ concentration was read at $240 \mathrm{~nm}$ in a spectrophotometer. Activity of catalase was expressed in katals (kat), i.e. moles of $\mathrm{H}_{2} \mathrm{O}_{2}$ decomposed per second. Peroxidase ( EC 1.11.1.7) was assayed taking $\mathrm{H}_{2} \mathrm{O}_{2}$ as the substrate and guaiacol as the reduced co-substrate and the developed colour intensity due to tetraguaiacol formation was read at $470 \mathrm{~nm}$ following the method of Kar and Feierabend (1984). Superoxide dismutase (EC 1.15.1.1) was assayed by the method of Das et al. (2000) and here the inhibition of superoxide driven nitrite formation from hydroxyl amine hydrochloride was measured at $543 \mathrm{~nm}$. SOD activity is expressed in units. One unit of SOD is defined as the amount that inhibits $50 \%$ of nitrite formation under assay condition.

\section{Presentation Of Data}

All the experiments were performed for three times with three replicates in each time. The mean values with standard deviations are presented.

\section{Results And Discussion}

Brinjal plants grown in presence of different proportion of paper mill sludge and soil showed some alterations in the activities of antioxidant enzymes. The enzymes like superoxide dismutase, catalase and peroxidases are important antioxidative enzymes that play an important protective mechanism to combat against the oxidative damage. SOD catalyses the disproportion of superoxide free radicals to $\mathrm{H}_{2} \mathrm{O}_{2}$ and $\mathrm{O}_{2}$ and thereby prevents its accumulation (Halliwell and Gutteridge, 2007). In the present investigation, it is evident that the activities of SOD increased significantly than control. The increasing activity of this enzyme in 10\% sludge treatment shows the increasing capacity of the cells to scavenge the superoxide radicals generated. Catalase eliminates $\mathrm{H}_{2} \mathrm{O}_{2}$ by breaking it down directly to form $\mathrm{H}_{2} \mathrm{O}$ and $\mathrm{O}_{2}$ and thus reduces its accumulation (Elstner, 1982). In this study, catalase activity was found to be enhanced in $10 \%$ sludge treatment. It clearly indicates that this treatment provides maximum protection against deleterious $\mathrm{H}_{2} \mathrm{O}_{2}$. Unlike catalase, peroxidases are also $\mathrm{H}_{2} \mathrm{O}_{2}$ scavenging enzymes and the activity of this enzyme increased further in the same treatment. Thus it is evident from the results that $10 \%$ sludge treatment is optimum for plant growth having more antioxidative efficiency. The results of the above three experiments are presented in fig. 1.

Lipid peroxidation is the result of free radical mediated reactions in aerobic cells and acts as an indicator of oxidative stress occurrence (Kappus, 1985). Lipid peroxidation level was measured in this study by measuring the content of malondialdehyde (MDA) in the tissues. It was found that the level of MDA declined in $10 \%$ sludge treatment showing ideal condition for plant growth. The results of the present study reveal that among the four treatments taken, $10 \%$ sludge treatment puts significant effect in developing the antioxidative system of plant.

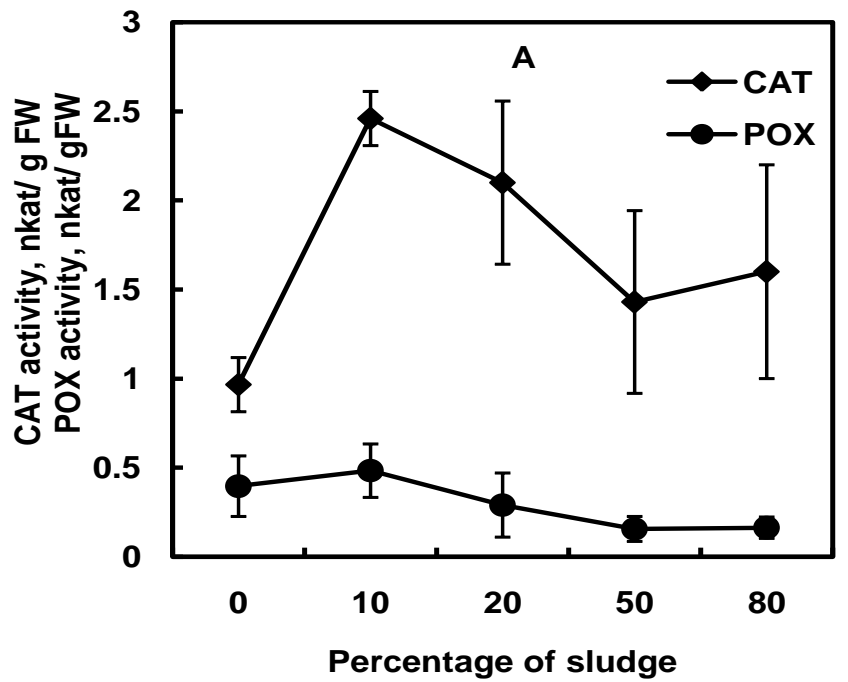




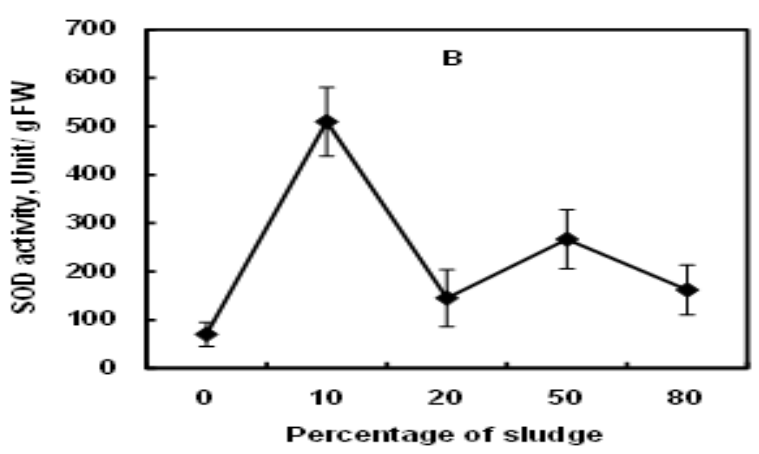

Fig. 1. Changes in catalase, peroxidase (A) and superoxide dismutase (B) activities in leaf tissues of Solanum melongena $\mathrm{L}$. under paper mill sludge treatment.

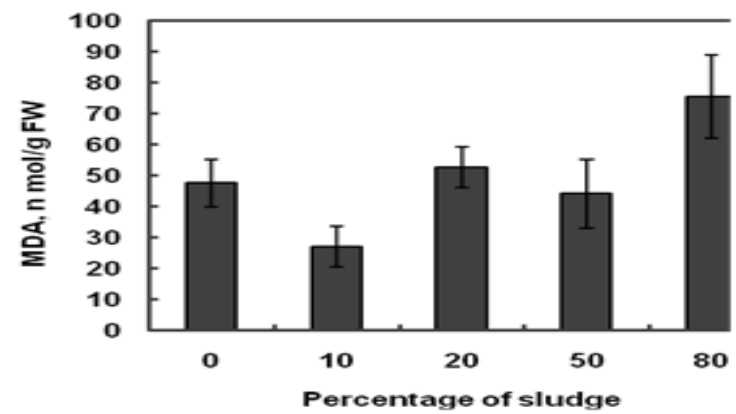

Fig- 2. Changes in the lipid peroxidation level in leaf tissues of Solanum melongena L. under paper mill sludge treatment.

\section{Conclusion}

In the present study, 10\% sludge treatment was found to be effective for better growth and development of the plant. The findings also indicate that at this treatment the plant develops its antioxidant defence system. Further study about heavy metal content will clearly conclude its ecotoxic effects.

\section{Acknowledgements}

The authors are thankful to the Head of the Department of Environmental Science, Fakir Mohan University for providing necessary laboratory facilities to carry out the research work.

\section{References}

[1] B. G. Billitewski, G. Hardtle and Marek, K. , Abfall-wirtschaft. Springer, Berlin. 1990.

[2] J. Hocking, Regulation of discharge of agrochlorines from pulp mills in Canada. Environ. Mgmt. 15, 1991, $195-204$.

[3] L. Beyer, K. Mueller, Combined application of secondary paper mill sludges and cattle slurry: Soil risk or soil improvement. Toxicological and Environmental Chemistry, 47, 1995, 243-249.

[4] J.H. Edwards, Composition and use of uncomposted waste paper and other organics, 1997, p. 163-184.

[5] B. V. Somashekaraiah, K. Padmaja, K. Prasad, and A. R. K., Phytotoxicity of cadmium ions on germinated seedlings of mung bean (Phaseolus vulgaris): involvement of lipid peroxide in chlorophyll degradation, Journal of Plant Physiology, 85, $1992,85-89$.

[6] A. Chaoui, S. Mazhoudi, M. N. Ghorbal, M. N. Ferjani, E. E., Cadmium and zinc induction of lipid peroxidation and effects on antioxidant enzymes activities in bean (Phaseolus vulgaris L. ), Journal of Plant Sci., 127, 1997, $139-147$.

[7] J. E. J. Weckx and H. M. M. Clijsters, Zn phytotoxicity induces oxidative stress in primary leaves of Phaseolus vulgaris, Journal of Plant Physiol. Biochem., 35, 1997, 405-410.

[8] W. Ch. Fang and H. Ch. Kao, Enhanced peroxidase activity in rice leaves in response to excess iron, copper and zinc, Journal of plant Sci.,158, 2000, 71- 76.

[9] R. K. Tewari, P. Kumar, P. N. Sharma and S. S. Bisht, Modulation of oxidative stress responsive enzymes by excess cobalt, Journal of Plant Sci., 162, 2002, 381- 388.

[10] R. L. Heath and L. Packer, Photooxidation in isolated chloroplasts. I. Kinetics and Stoichiometry of fatty acid peroxidation. Arch. Biochem. Biophys. 125, 1968, 189-198.

[11] H.E. Aebi, Catalase. In: H.U. Bergmeyer (ed.), Methods of Enzymatic Analyses, Verlag Chemie, Weinheim. Vol. 3, 1983, pp. 273285.

[12] M. Kar and J. Feierabend, Metabolism of activated oxygen in detached wheat and rye leaves and its relevance to the initiation of senescence. Planta. 160, 1984, 385-391.

[13] K. Das., L. Samanta, G. B. N. Chainy, A modified spectrophotometric assay of Superoxide dismutase using nitrite formation by superoxide radicals. Ind. J. Biochem. Biophys. 37, 2000, 201-204.

[14] B. Halliwell and J. M. C. Gutteridge, Free radicals in Biology and Medicine. 4th Edn. Oxford University Press, New York, 2007.

[15] E. F. Elstner, Oxygen activation and oxygen toxicity. Annu. Rev. Plant Physiol. 33, 1982, 73-96.

[16] H. Kappus, Lipid peroxidation: Mechanisms, analysis, enzymology and biological relevance, in: H.Sies (Ed.), Oxidative stress, academic Press, London, 1985, 273-310. 